\title{
Second Language Acquisition in Informal Setting
}

\author{
Taher Bahrani (Corresponding author) \\ Department of English Language, Mahshahr Branch, Islamic Azad University, Mahshahr, Iran \\ Tam Shu Sim \\ Department of English, Faculty of Languages and Linguistics, University Malaya, Malaysia \\ Marziyeh Nekoueizadeh \\ Department of English Language, Marvdasht Branch, Islamic Azad University, Marvdasht, Iran
}

\begin{abstract}
For second language acquisition (SLA), having access to language input is critical. Although the theories of SLA attach different importance to the role of language input, they all acknowledge the need for it (Ellis, 2008). Learners of English as a second (ESL) or a foreign language (EFL) are always encouraged to avail themselves of all forms of authentic language input within the classroom and beyond. In contexts with limited social interaction in the English language, however, various audiovisual technologies are available to be utilized as sources of authentic language input for enhancing language learning in both formal and informal learning settings. In the same line, the present aims at considering the role of language input for SLA development in informal setting.
\end{abstract}

Index Terms - second language acquisition, informal setting, authentic language input

\section{LANGUAGE INPUT AND SECOND LANGUAGE ACQUISITION}

In this section, the role of language input in SLA is discussed. This is done based on: firstly, the importance which is given to the role of input in various theories of language learning, and secondly, some frameworks for SLA such as those introduced by Gass and Selinker (1994) and Ellis (1997) with the direct focus on language input for SLA. Additionally, Krashen's input hypothesis is followed by critiques of his hypothesis.

The role of input in second language acquisition

There are many internal as well as external factors which influence SLA. Among them, the language input that learners receive in SLA is one of the external factors which plays a fundamental role. Corder (1967) is one of the pioneers among SLA researchers who underscored the importance of language input for SLA by drawing a distinction between input and intake. According to Corder, language input refers to what is available to be utilized by language learners for SLA which should be differentiated from intake which is that part of the input which is comprehended by the language learners.

The review of the literature on language input and SLA reveals that much work in this area of research has been concerned with the importance, the role, and the processing of linguistic input (Doughty \& Long, 2003; Ellis, 1994; Ellis, 1997; Gass \& Selinker, 1994; Gass, 1997). From a large pool of research, it can be deduced that SLA simply cannot take place in a vacuum without considering having exposure to some sort of language input (Gass, 1997).

However, while the importance and the role of language input have been advocated by various theories of language learning, there has been a difference between those theories which attribute a small or no role to language input and those attributing it a more important role. According to Ellis $(1994 ; 2008)$, SLA theories attach different importance to the role of input in the language acquisition process but they all acknowledge the need for language input. In many SLA theories, language input is considered as being a highly essential factor while in other theories it has been given the secondary role. In fact, what has been changed in relation to the role of input in language learning from the viewpoint of various language learning theories is the conceptualization of how language input is processed by language learners (Doughty \& Long, 2003).

In this relation, Ellis (2008) considered the role of language input in SLA based on behaviorist, mentalist, and interactionist theories of language learning. Gass (1997) also considered the role of language input in the inputinteraction model, the input hypothesis, the universal grammar model, and the information processing model which treat the role of language input in different ways. According to Gass (1997), in the input-interaction model, the language input that language learners receive is strengthened by the manipulation of the input through interaction which forms a basis for SLA. Within Krashen's comprehensible input hypothesis (1981), SLA takes place merely by means of comprehensible input which the language learners receive. That is, only the language input that is a little beyond the learners' language competence is useful for SLA. The third model as explained by Gass (1997) is the universal grammar which asserts that language input is important but there must be something in addition to language input. This is the innate capacity which helps language learners acquire the second language. The last model is the information processing model in which the learner must first notice that there is something to learn. Then, the learner's attention is 
drawn to those parts of the input which do not coincide with the internalized competence. In this model, language input is necessary for providing information for language construction (Gass, 1997).

Besides the role of language input in SLA which has been considered from the perspectives of different language learning theories and models, language input has also been given the initial role to provide the necessary data for SLA in some frameworks. Among the researchers who have studied the role of language input in SLA, Gass and Selinker (1994) and Ellis (1997) proffered two frameworks which indicate the importance of input in the SLA process.

Within the framework introduced by Gass and Selinker (1994), there are five levels for turning input into output: apperceived input, comprehended input, intake, integration, and output which account for the SLA process. According to their model (Figure 1), language input refers to various sources of second language data which the learners are exposed to.

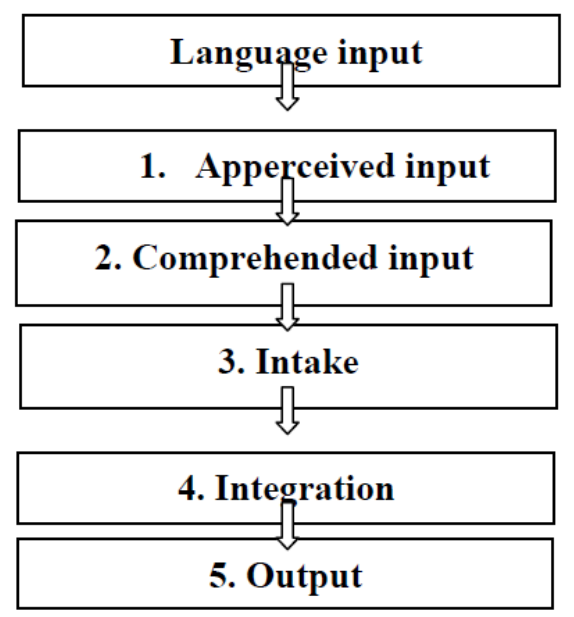

Figure 1: Gass and Selinker's model (1994) for second language acquisition

The first stage of the SLA model which is concerned with input utilization is called apperceived input. In this stage, some of the language input is noticed by the language learner because of some specific features such as frequency, prior knowledge, affect, and attention (Gass \& Selinker, 1994). The second stage is the comprehension of that bit of language input which is apperceived. Then, in the third stage which is a mental activity, the language input is comprehended and internalized by the language learners which refers to intake. The fourth stage is the integration of the intake with the prior knowledge to arrive at the fifth stage which is the output in the form of written or spoken language.

Likewise, Ellis (1997) introduced a basic computational model of SLA with an initial focus on language input (Figure 2). In this model, language learners are first exposed to language input which is then processed in two stages. First, some parts of the input that are comprehended by the language learners turn into intake. Second, some of the intake which finds its way to the long term memory is then turned into knowledge which results in spoken or written output. While Gass and Selinker's (1994) and Ellis's (1997) theoretical frameworks for SLA attach the initial importance to language input, they differ from each other in the number of stages that language input is processed in the minds of language learners.

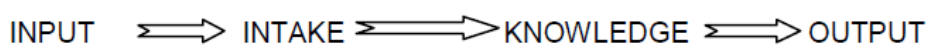

Figure 2: Ellis's model (1997) for second language acquisition

In a nutshell, both the above-mentioned frameworks are concerned with the various steps in which language input is turned into output. In other words, the language input processing is the focus of both frameworks. However, comparing the theories and theoretical frameworks for SLA based on the role of language input, it is revealed that the importance of language input is highlighted by various theories and theoretical frameworks for SLA. Taking up on this, one of the most influential SLA hypotheses concerned with the role and importance of language input in SLA is the input hypothesis (Krashen, 1981, 1982, 1985). Indeed, most of the studies on the type of language input and SLA have been developed to either support or criticize Krashen's input hypothesis which first claimed the important role of comprehensible input for SLA. Indeed, input hypothesis triggered numerous studies in the investigation of issues related to the type of language input for SLA (Ying, 1994).

\section{Krashen's input hypothesis and second language acquisition}

One of the important psychologically-oriented theories of language learning was established by Krashen (1981, 1982, 1985). He proposed a 'monitor model' of second language learning including five hypotheses: the input hypothesis, the natural order hypothesis, the acquisition-learning hypothesis, the monitor hypothesis, and the affective filter hypothesis. The hypothesis related to this study is the input hypothesis which is put forth. 
The input hypothesis strongly claims that for SLA to take place, language learners should have exposure to a type of second language data which they can comprehend. Krashen identified comprehensible language input as "the only causative variable in SLA" (Krashen, 1981, p. 57). According to Krashen, for SLA to occur, language learners have to have exposure to comprehensible language input that includes language structures that are beyond their current level $(\mathrm{i}+1)$.

Based on Krashen's claims regarding language input and SLA, the basic assumptions of the input hypothesis are summarized as: (1) access to comprehensible input is the main feature of all cases of effective SLA, (2) more quantities of comprehensible input seem to cause faster or better SLA, and (3) lack of access to comprehensible input causes little or no SLA.

A few researchers (Ellis \& He, 1999; Gass \& Varonis, 1994; Long, 1982) have advocated the input hypothesis by suggesting modified input, interactionally modified input, and modified output as three rich sources of comprehensible input for SLA. Modified input refers to a type of language input that has been modified or simplified in some ways before the language learners are exposed to it, interactionally modified input, on the other hand, originates from input modification that occurs when language learners experience difficulty comprehending a message in interaction with interlocutors, and modified output refers to language learners' efforts to modify their output to make it more comprehensible to the interlocutor (Ellis \& He, 1999; Long, 1996).

Another aspect of the input hypothesis in relation to acquiring the language in informal settings (out of the classroom environment) is the importance of direct exposure to a source of language input. According to Krashen (1981), language acquisition can take place in an informal environment if language learners are directly involved in intensive exposure to language input. Later, it will be discussed that this aspect of the input hypothesis which emphasizes the necessity of exposure to language input for language learning to occur has also been emphasized by Krashen's critics. Nevertheless, empirical evidence related to the sources of language input, the quality, and quantity of the input have not been provided neither by Krashen nor his critics.

\section{Critiques of the input hypothesis}

Regardless of the significant effect that the input hypothesis has had on the researches about the role of language input in SLA, it has been criticized strongly by several researchers. Serious concerns regarding the input hypothesis were expressed by McLaughlin (1987). McLaughlin claimed that it is very difficult to define the concept of a learner's level which limits the application of its rule in the classroom because individual differences should be taken into consideration when determining the learners' current levels. In fact, determining the current level of each language learner and providing i+1 language input for each of them separately in the classroom seems to be very difficult to fulfill. Krashen did not provide solutions considering this issue. There are also some problems regarding the approach to provide language learners with language input which matches their" i+1" level.

The input hypothesis has also been challenged by many researchers particularly because it has made a large number of claims about the type and the qualitative aspect of the necessary language input for SLA development without providing solid empirical evidence. In other words, because Krashen's input hypothesis limits SLA to merely exposure to comprehensible input, the criticisms directed at the input hypothesis are mainly around the nature and the type of language input that can constitute the primary data for SLA. In fact, although second language researchers and the critics of Krashen's input hypothesis highlight the important role of input in SLA and agree on the fact that language input is a necessary ingredient in SLA (Salaberry, 2003), they claim that SLA is not achieved merely through comprehensible input. Other types of language input such as incomprehensible input, comprehended input, and comprehensible output are also considered to improve language learning through providing the necessary input.

White (1987) considered the necessary language input which constitutes the primary data for SLA to be either comprehensible or incomprehensible. In his incomprehensible input hypothesis, White underscored the point that it is the comprehension difficulties or input incomprehensibility that can provide important negative feedback to the learner that is indispensable for the constitution of SLA. When language learners encounter language input that is incomprehensible to them because their inter-language rules cannot, for example, analyze a particular structure, they have to modify those inter-language rules to understand the structure (White, 1987). As a result, the incomprehensible input enhances SLA.

It can be concluded from what White (1987) has put forth in relation to comprehensible or incomprehensible input that when the language input is comprehensible, the acquisition of the missing structures may not occur. In contrast, when the language input is incomprehensibility because of some aspects which the language learners have not yet acquired, the given language input to the language learners draws their attention to the specific features to be acquired.

Gass $(1988,1997)$ also emphasized that priority should be attached to the concept of comprehended input rather than comprehensible input. According to Gass, only that part of the language input which is comprehended is involved in the SLA process. In other words, the primary language input which is necessary for SLA may be beyond the boundaries of comprehensible input.

In the same line and as was discussed earlier, in Gass and Selinker's (1997) and Ellis's (1994) theoretical models for SLA, language input which is apperceived by the language learners and then is turned into comprehended input and intake is not limited merely to language data (input) which should necessarily be comprehensible. Indeed, language learners are exposed to a body of second language input which may or may not be within the range of $i+1$. Out of this 
initial body of language input, some of the input is noticed by the language learners because of frequency, affect, prior knowledge, and attention (Gass \& Selinker, 1997). Hence, the qualitative aspect of language input in Gass and Selinker's (1997) and Ellis's (1994) theoretical models for SLA is not limited to language input that is necessarily at the language learners' $\mathrm{i}+1$ current language proficiency level.

In addition to incomprehensible input and comprehended input, Swain (1985) also argued that besides comprehensible input, comprehensible output can also provide the necessary data for SLA. The comprehensible output hypothesis put forth by Swain (1985) states that language learning occurs when the language learner faces a gap in his/her linguistic knowledge of the second language. By noticing this gap, the language learner tries to modify his/her output. This modification of output may end in learning a new aspect of the language which has not been acquired yet.

Although Swain did not claim that comprehensible output is solely responsible for all or even most parts of the language acquisition, she highlighted the point that under some conditions, comprehensible output facilitates SLA in ways that it can provide the necessary input. As a matter of fact, although Swain (1985) acknowledged that without comprehensible input language learners are not able to make connections between forms and meanings for SLA development, she provided evidence of the immersion programs in which comprehensible input alone did not lead to SLA. This view sharply contrasts with Krashen's input hypothesis where the role of comprehensible output is neglected or minimized.

To this point, according to what was put forth in relation to Krashen's input hypothesis and his critiques' concerns, it can be concluded that the importance of language input for SLA is not questioned and some type of language input is necessary for SLA. Accordingly, in addition to modified input, interactionally modified input, and modified output which are considered as various types of comprehensible input for SLA, comprehended input, incomprehensible input, and comprehensible output can also provide the necessary language input for SLA. Hence, without debating on the right or wrong of Krashen's hypothesis which is beyond the scope of this study, the premise taken is that some forms of language input is necessary for the study without delving into the psychological aspects of the language input.

\section{INFORMAL AND FORMAL LANGUAGE LEARNING SETTINGS}

The term informal learning was drawn from informal education which was first introduced and popularized in the field of education by Knowles (1950). In focusing on the concept of informal education, Knowles highlighted the informal environment in many learning situations, the flexibility of the process, and the use of experience. Although Knowles did not explicitly define informal education, he utilized the term to refer to the use of informal programs and, to some extent, the learning obtained from interaction in society. In the same line, Coombs and Ahmad (1974) defined informal education as a widely accepted process of developing knowledge and skills of people in a highly uninstitutional and unstructured setting. In contrast, formal education is highly institutional and occurs in structured settings.

Following the concepts of informal and formal learning, informal and formal language learning were also introduced and studied by some researchers (Lightbown \& Spada, 2001; Marsick \& Watkins, 1990; Rogers, 2004). In this regard, similar to Coombs and Ahmed, Rogers (2004) noted that informal language learning is unstructured and unpurposeful but is the most extensive and essential part of all the learning that all of us do every day of our lives. On the contrary, formal language learning is structured, purposeful, and school-based.

The distinction between formal and informal language learning is significant in terms of the settings of the learning (in-or-outside the class environments), and instruction which refers to focus on the form or the meaning of language (Lightbown \& Spada, 2001; Marsick \& Watkins, 1990). Informal setting is considered as the context in which language learners are exposed to the target language at school, home, and work or in social interaction and formal setting as the context where the target language is being taught to a group of second or foreign language learners (Lightbown \& Spada, 2001).

In view of that, formal language learning takes place in the class environment but informal language learning, mostly, takes place out of the class environment. Nevertheless, it should be borne in mind that it is not always the case that formal and informal language learning settings are separate from each other and do not overlap. Informal language learning can also occur in a class setting when the focus is not on the form of the language (Marsick \& Watkins, 1990). Marsick and Watkins (1990) highlighted the point that informal language learning may occur in classrooms or institutions when peers have interaction with each other, but it is not typically classroom-based or highly structured. Moreover, informal learning can be deliberately encouraged where the environment is not highly conducive to learning. Figure 3 shows the comparison between formal and informal language learning in terms of settings and instructions. 


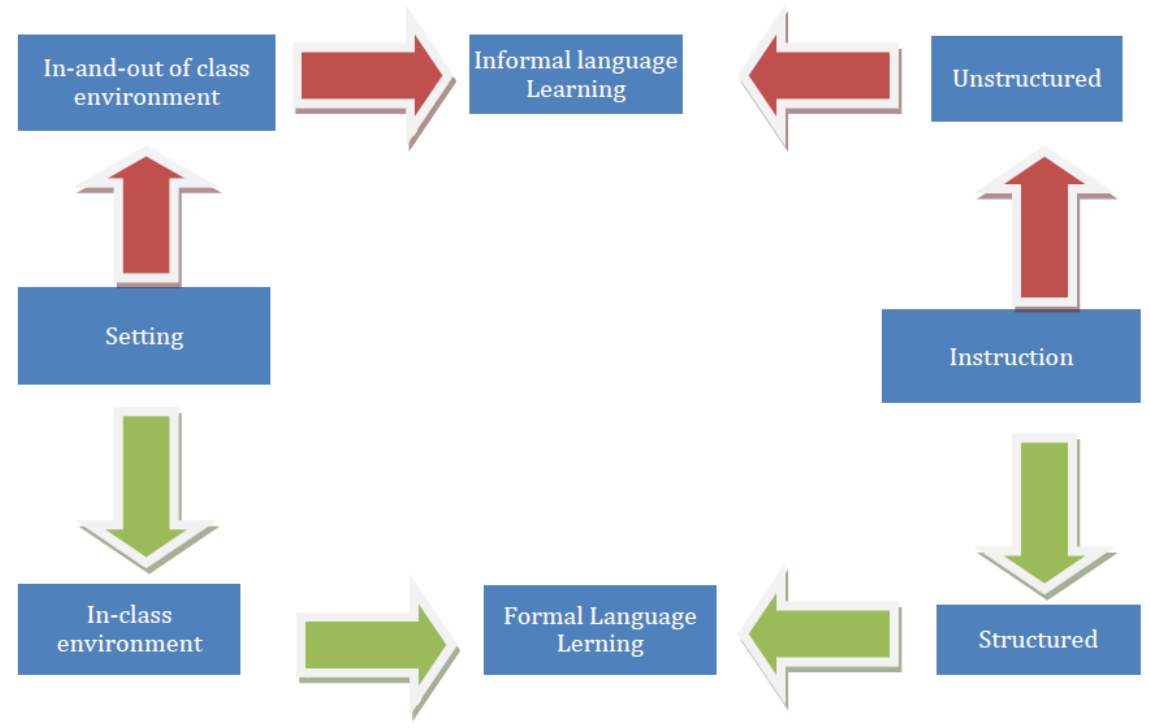

Figure 3: Graphic representation of the distinctions between formal and informal language learning in terms of setting and instruction

Based on what Marsick and Watkins (1990) put forth, formal language learning is classroom-based, highly structured, and teacher-directed in terms of the content to be learnt. Conversely, informal language learning occurs in-and-out of classroom while the focus is not on the form of the language. Moreover, informal language learning is not structured.

Considering the fact that some type of language input is required for language learning/acquisition, one issue in relation to acquiring the language in informal settings in EFL/ESL contexts is the source of language input.

\section{SOURCES OF LANGUAGE INPUT IN EFL/ESL CONTEXTS}

Various sources of language input are available in ESL and EFL contexts. Before the discussion on the sources of language input in EFL and ESL contexts is put forth, the concepts of ESL and EFL contexts need to be elaborated.

An ESL context is an environment where English language is spoken in society as the official language or the medium of communication among people from different countries. In fact, English language plays an institutional and social role in the community in an ESL context (Ellis, 2008). According to Ellis (2008), in an ESL context, English language functions as a means of communication among members who speak various languages. In contrast, an EFL context refers to an environment where English language is not the primary or secondary language spoken. Indeed, English is considered as a foreign language rather than a second language and the use is limited to language classrooms (Freed, 1995). In EFL context, English language has no major role in society and is learnt in the classroom setting (Ellis, 2008).

Back to the discussion on the available sources of language input in EFL/ESL contexts, it should be mentioned that in ESL contexts, people can have interaction with other people from different countries using the English language. English is then considered as a source of language input which can facilitate and pave the way for SLA (Gass, 1997). The social interaction in ESL contexts is one of the authentic sources of language input which can help language learners acquire the language in informal settings.

This has been emphasized by Long's (1996) Interaction Hypothesis in which conversational interaction enhances SLA. Accordingly, negotiation of meaning which triggers interactional adjustments by the native speakers or more proficient interlocutor in social interaction can contribute to SLA. In contrast, in an EFL context social interaction as a source of language input in an informal language learning setting is lacking. English is not used as a medium of communication or for other purposes in society in the EFL contexts. Indeed, the use of English language is mainly limited to formal settings at universities, language institutes or language classrooms. As a matter of fact, in EFL contexts, limited usage of English language can only be observed when language learners use English language in interactions with their instructors and their peers.

In short, examples of learning the language in informal setting include learners' interaction with native or non-native speakers in the target language country or a country where English is the second language. Besides, learners' use of different technologies at home or at work via watching a movie or listening to music or song which provide appropriate language input is considered as another example of language learning in informal settings (Lightbown \& Spada, 2001).

By viewing, for example, a movie or listening to a song, language learners indirectly get involved in the language learning process when they try to understand the movie or the song by using different language learning strategies (Pemberton, Fallahkhair \& Mosthoff, 2004). The various types of audiovisual programs are considered to be authentic language materials which have the potential to provide the necessary language input for SLA in informal setting by indirectly involving the language learners in the language learning process (Pemberton et al., 2004). 


\section{Authentic LANGUAGE INPUT FOR SLA DEVELOPMENT}

In this section the concept of authentic language input needs to be defined first. Then, the sources of authentic language input which are available in EFL and ESL contexts will be highlighted. Lastly, the benefits and possible drawbacks of utilizing authentic language input in language learning are considered.

\section{Defining authenticity}

Using authentic language input through authentic materials in foreign/second language learning has a long history. For example, Henry Sweet (1899, cited in Gilmore, 2007) is considered as one of the first linguists who utilized authentic texts because he was aware of their potential advantages over contrived materials.

In order to determine the definition of authentic language input as precisely as possible, the term authenticity should be considered first. In this regard, there are varieties of definitions of this concept which relate to second/foreign language classroom (Gilmore, 2007; Nunan, 1999; Porter \& Roberts, 1981; Taylor, 1994; among others). These various definitions emerge from the debate as to whether authentic materials which are utilized in language classrooms are in fact considered to be authentic or inauthentic.

Taylor (1994) considered different types of authenticity as falling into three categories: authenticity of the task, authenticity of language input, and authenticity of the situation. Authentic language input is any material which has not been explicitly prepared for the purpose of language teaching such as movies, singing shows, stories, games, and plays. Although these materials are not made for language teaching purposes, they contain the characteristics of language used by the native speakers (Taylor, 1994).

In relation to the concept of authentic language input, Nunan (1999) described authentic language materials as written or spoken language materials that have been produced in real communication. In fact, these spoken or written language materials are not specifically produced for the very purpose of language teaching. Nunan (1999) further highlights the assumption that authentic language input can be extracted from various sources such as news, movies, singing shows, series, and comedies, recorded conversations, meetings, and newspapers. Gilmore (2007) also defined authentic language input as the language conveying a real message which is produced by a real speaker or writer for a real audience. In short, the point can be concluded that authentic materials that are not initially made for language teaching purposes can be extracted from various print or audiovisual sources.

\section{Sources of authentic language input in EFL/ESL contexts}

There are varieties of authentic teaching sources and materials available to EFL/ESL teachers to utilize for different needs for various teaching situations in formal as well as informal language learning settings. As was discussed earlier, while social interaction as an authentic source of language input is not available in EFL contexts, many other sources of authentic language input are available in both EFL and ESL contexts. In this relation, desktop technology such as computers and non-desktop technologies such as TV and radio can provide easy access to authentic language input for SLA in both EFL and ESL contexts.

The review of the literature on the integration of different audiovisual programs as sources of authentic language input for language learning highlight the pedagogical value of such materials. As Gebhard (1996) put forth, there are unlimited sources of authentic language materials from various audiovisual sources such as TV commercials, singing shows, cartoons, news clips, quiz shows, comedy shows, movies, series, and documentaries that language teachers and learners can use for language learning purposes.

\section{Audiovisual Technologies as Sources of Authentic Language InPut}

Computers as a type of desktop technology have systematically been used in teaching and learning of foreign/second languages since the 1960s. The early use of computers in language learning both in informal and formal language environments constituted an extension and development of the work done in the audiovisual language labs. The pedagogical effectiveness of computer-assisted language learning in formal and informal settings also began with the development of the capacities of computers. In fact, the remarkable developments in audiovisual and computermediated communication programs provided many possibilities for teachers to construct activities for second language learning.

Considering the fact that in the last few years audiovisual technology has dominated the world by showing different programs both to instruct and entertain various audiences, many studies have focused on the incorporation of computers as an audiovisual technology that can provide authentic language input for SLA in formal as well as in informal language learning settings in ESL/EFL contexts.

Regarding the use of computers in informal settings of language learning, Adams, Morrison, and Reedy (1968) noted that computers have the potential not only to supervise language learners' performance in informal settings but also to monitor, record, analyze, and summarize data about their learning. Decker (1976) also argued that most significantly, computers provide instant feedback through correcting exercises and tests. This application of computers for language learning has been based on the behaviorist approach that emphasizes stimulus and response for habit formation. In other words, language learners use the computers to learn the language in both formal and informal learning settings through a number of repetition and drills which are believed by the behaviorist theory of learning to boost language learning. 
Although, the application of computers in language learning has apparently gone beyond limited repetition and drills since the 1980s, it still reflected the behaviorist viewpoint. Egan (1999) developed a computer-based software program requiring the language learners to get engaged in language learning through doing some exercises such as filling the blanks, choosing the correct answers, practicing in reading and listening to authentic written and spoken language, producing language by repeating words or sentences, recording their responses and comparing them to native models (Egan, 1999).

Although Egan's software leads language learners to produce speeches through interaction with the computer, the interaction is based on stimulus and response which reflect the behaviorist approach. Language learners seem to be in charge of their learning but the authentic language input which is offered to them and what they can gain is limited to what the software offers. This limitation may break the interaction when the software lacks the necessary stored data for a particular stimulus or response. In other words, the critical point is that this type of interaction with machines rather than human beings can be limited at times. If one stimulus is not recognized by the software, the interaction may fail or may be directed to something rather than what the language learner intends. The reason behind this is that computers may not be able to negotiate for meaning to facilitate comprehension in a way which is done in real communication.

The acquisition of communicative language skills through computers makes it necessary to develop computer programs that engage the language learners in real interactive speaking activities with native or proficient non-native speakers or language learners in both formal and informal settings. In fact, the use of any technologies including computers to provide the necessary input for language learning in informal setting should not reflect the behaviorist view to language learning (Pemberton et al., 2004).

The point to be underscored is that in informal language learning setting compared to formal language learning setting, language learners are not supposed to get involved in a sort of activity which requires them to do repetitions and drills similar to that of the classroom settings. In fact, if different technological tools are to be utilized in informal settings for language learning, it should be unstructured, unconscious or unpurposeful (Rogers, 2004). As a result, informal language learning cannot be based on the behaviorist approach because it requires repetition and drills in informal settings similar to that of the formal settings.

Bray (2005) also claimed that the integration of computers for language learning in both formal and informal settings should not be based on the behaviorist theory. According to Bray, in informal language learning setting, adults like to have fun and have little desire to solve a problem. When it comes to learning the language in informal settings, language learners do not like to get involved in the same scenario which exists in most of the formal language learning settings. Informal language learning is in contrast to the behaviorist approach which requires language learners to do some repetitions and drills even in informal settings. In learning the languages in informal setting through, for example, the Internet as a computer based technology, language learners are self-directed, self-motivated, and have the ability to interact with other language learners using computer-mediated communication (Bray, 2005). In fact, the Internet can provide the language learners with a huge amount of authentic language input for SLA without requiring them to do any repetition and drills exercises.

To sum up, the important point to be underlined in relation to the application of computers as a desktop technology for language learning is that in most of the cases computers have been employed in informal language learning setting based on the behaviorist theories of language learning which does not comply with some of the criteria for informal language learning such as unstructured, unconscious or unpurposeful learning.

In recent years, however, the use of non-desktop technologies such as audiovisual devices, for example, television is also attracting increasing interest among many researchers in informal learning and SLA (Milton, 2002; Pemberton et al., 2004).

According to Milton (2002), mass media technologies can give the teachers as well as the learners a pool of activities and experiences that can reinforce language learning in informal settings as well as the formal settings of the school. Watching different programs, for example, on TV is a sort of activity in informal settings which can lead to language learning regardless of the fact that the focus is not on learning (Milton, 2002). In other words, language learners learn the language without directly getting involved in any sort of explicit language learning activities. However, in highlighting the pedagogical value of exposure to mass media technology, Milton did not further specify what type of mass media technology can boost language learning in informal language settings. Also, he did not provide any details on the amount of exposure to a specific type of mass media which may lead to language improvement. More importantly, in his study, language learners were required to do some exercises in informal settings which does not comply with informal language learning criteria.

Another study concerning the use of non-desktop technology such as interactive television to provide authentic language input for language learning in informal setting was conducted by Pemberton et al. (2004). The foremost rationale of the study was to focus on the learning potential of interactive television in informal settings, currently available in the UK and some other countries via cable and satellite technologies. According to Pemberton et al., unlike conventional television, interactive TV allows the users to interact with each other and also provides new facilities for information retrieval and communication.

In order to support the great potentiality of interactive TV for language learning in informal settings, Pemberton et al. (2004) based their claim on a sound pedagogical framework that was derived from language learners' interests, 
motivations, and learning styles. Furthermore, the study considered the possibility of using interactive TV in informal setting based on different language learning theories such as constructionist and constructivist.

According to the constructionist view, the acquisition of language can occur through exposure to authentic language input in informal settings (Pemberton et al., 2004). In this regard, various audiovisual programs from different nondesktop technologies such as TV have the potential to be utilized as authentic sources of language input in informal settings. The study of Pemberton et al. (2004) supported the constructionist approach through the use of subtitle which provided comprehensible input. The participants of the study were given a language learning version of subtitles that provided extra language support, which could help language learners to understand more from their viewing.

The study also supports the self-directed language learning approach which reflects one of the characteristics of informal language learning. The constructivist approach can be supported by enabling language learners to create their own learning space that can be accessed anytime or anywhere. Accordingly, language learners are in charge of selecting their preferred type of language learning material through interactive TV which enables them to be in charge of their own learning experience. In fact, in learning the language through interactive TV in informal language learning setting, language learners want to sit back and relax while being immersed in pedagogically valuable authentic audiovisual programs and to be able to get extensive support to help them gain more from their foreign language viewing (Pemberton et al., 2004).

In short, the above discussed study anecdotally considered the pedagogical value of interactive TV as a type of nondesktop technology in informal settings for language learning and its application based on different language learning approaches. It also focused on introducing a framework to support the use of interactive TV as a source of authentic language input in informal settings. However, the study lacks empirical evidence of the effect of exposure to TV on SLA. Furthermore, it focused on interactive TV rather than conventional TV or satellite TV which is readily available around the globe.

\section{CONCLUSION}

One of the essential issues in SLA which has been the focus of many studies in the last three decades is language input and its role in SLA. Among the pool of researchers, Krashen (1982) claimed that language acquisition can happen in formal and informal language learning settings only if language learners are directly involved in intensive exposure to a type of input which is comprehensible. In contrast to this claim, other researchers also considered comprehended input (Gass, 1988, 1997) incomprehensible input (White, 1987), and comprehensible output (Swain, 1985) to provide the necessary language input for SLA.

Considering the fact that some sort of language input is necessary for SLA in both formal and informal settings, authentic language materials have the potential to be used as sources of language input for SLA which can indirectly involve the language learners in the language learning process. In the same line, the remarkable developments in audiovisual technologies recommend many possibilities for teachers to construct activities for second language learning by providing easy access to authentic language input for language learners in both EFL and ESL contexts.

Since the 1970s, the application of various authentic programs such as news, movies, singing shows, cartoons, and comedies from various audiovisual technologies such as satellite or conventional TV to provide the necessary language input for SLA have also been attracting increasing interest among researchers.

However, while there is an agreement on the use of various types of audiovisual programs as sources of authentic language input particularly in classroom environment for language learning, little empirical evidence has been provided about their effects on the enhancement of language proficiency in informal setting. To bridge the gap, the opportunities for informal language learning through exposure to various audiovisual programs as sources of authentic language input in EFL/ESL contexts may be the subject matter of future research.

\section{REFERENCES}

[1] Adams, E., H. Morrison, \& J. Reddy. (1968). Conversation with a computer as a technique of language instruction. Modern Language Journal 52, 3-16.

[2] Bray, C. (2005). Watching the whale watchers: leisurely informal learning online. Retrieved (05/28//2005) from http://: www.Orcac-live.net.

[3] Corder, S. P. (1967). The significance of learners' errors. International Review of Applied Linguistics 5, 161-170.

[4] Decker, H. (1976). Computer-aided instruction in French syntax. Modern Language Journal 60, 263-273.

[5] Doughty, C., \& M. H. Long, (2003). The handbook of second language acquisition. London: Blackwell publishing.

[6] Egan, K. (1999). Speaking: A Critical Skill and a Challenge. CALICO Journal 16(3), 277-293.

[7] Ellis, R. (1994). The study of Second language acquisition. Oxford: Oxford University Press.

[8] Ellis, R. (1997). SLA research and language teaching. Oxford, England: Oxford University Press.

[9] Ellis, R. (2008). The study of Second language acquisition (Second Ed.). Oxford: Oxford University Press.

[10] Ellis, R., \& X. He. (1999). The roles of modified input and output in the incidental acquisition of word meanings. Studies in Second Language Acquisition 21, 285-301.

[11] Freed, B. (1995). Second language acquisition in a study abroad context. Amsterdam: John Benjamins.

[12] Gass, S. M. (1997). Input, interaction, and the second language learner. Mahwah, NJ: Lawrence Elrbaum. 
[13] Gass, S., \& L. Selinker, (1994). Second language acquisition: an introductory course. Hilldale, NJ: Lawrence Erlbaum Associates.

[14] Gass, S., \& E. Varonis. (1994). Input, Interaction, and Second language production. Studies in Second Language Acquisition 16, 283-302.

[15] Gebhard, J. G. (1996). Teaching English as a Foreign Language: A Teacher Self-Development and Methodology Guide. Ann Arbor: The University of Michigan Press.

[16] Gilmore, A. (2007). Authentic materials and authenticity in foreign language learning. Lang. Teach. 40, 97-118.

[17] Knowles, M. S. (1950). Informal adult education. New York: Association Press.

[18] Krashen, S. (1981). Second language acquisition and second language learning. Oxford: Pergamon Press.

[19] Krashen, S. (1982). Principles and practice in second language acquisition. New York: Prentice Hall.

[20] Krashen, S. (1985). The input hypothesis. Torrance, CA: Laredo Publishing Company.

[21] Lightbown, P. M., \& N. Spada, (2001). How Languages are Learned, Second edition, Oxford University Press, Oxford.

[22] Long, M. (1982). Native speaker/non-native speaker conversation in the second language classroom. In M. Long \& C. Richards (Eds.), Methodology in TESOL: A book of readings (pp. 339-354). New York: Newbury House.

[23] Long, M. (1996). The role of the linguistic environment in second language acquisition. In W. C. Ritchie \& T. K. Bhatia (Eds.), Handbook of second language acquisition (pp. 413-468). New York: Academic Press.

[24] McLaughlin, B. (1978). The monitor model: some methodological considerations. Language learning 28, $309-332$.

[25] Marsick, V. J., \& K. Watkins, (1990). Informal and Incidental Learning in the Workplace. London and New York: Routledge.

[26] Milton, J. (2002). Literature Review in Languages, Technology and Learning. Nesta Future Lab Series: Report1.

[27] Nunan, D. (1999). Second Language Teaching and Learning. Boston: Heinle and Heinle Publishers.

[28] Pemberton, L., S. Fallahkhair, \& G. Masthoff, (2004). Toward a theoretical framework for informal language learning via interactive television. Paper Presented In Proceedings of IADIS International Conference of Cognition and Exploratory Learning in Digital Age. Lisbon, Portugal.

[29] Porter, D., \& J. Roberts, (1981). Authentic listening activities. English Language Teaching Journal 36(1), 37-47.

[30] Rogers, A. (2004). Looking again at non-formal and informal education - towards a new paradigm. The encyclopedia of informal education, www.infed.org/biblio/non_formal_paradigm.htm. Last updated: June 04, 2004.

[31] Salaberry, M. R. (2001). The use of technology for second language learning and teaching: A retrospective. Modern Language Journal 85(1), 39-56.

[32] Swain, M. (1985). Communicative competence: Some roles of comprehensible input and comprehensible output. In S. Gass \& C. Madden (Eds.), its development Input in Second Language Acquisition. Newbury House, Rowley, Mass.

[33] Sweet, H. (1899). The practical study of languages. London: Oxford University Press.

[34] Taylor, D. (1994). Inauthentic authenticity or authentic inauthenticity? Teaching English as a Second or Foreign Language 1, $1-10$.

[35] White, L (1987). Against comprehensible input: The Input Hypothesis and the development of L2 competence. Applied linguistics 8, 95-110.

[36] Ying H. (1994). What sort of input is needed for intake? SLAT student association working papers 2 (1), 28-40.

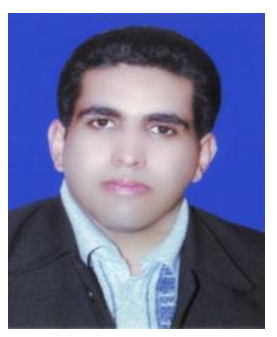

Taher Bahrani was born in 1979 in Iran. He is a Ph.D holder in TEFL from the University of Malaya. He has published 4 ISI-indexed papers and many peer-reviewed ones. He is also the editor-in-chief of the international journal of language learning and applied linguistics world.

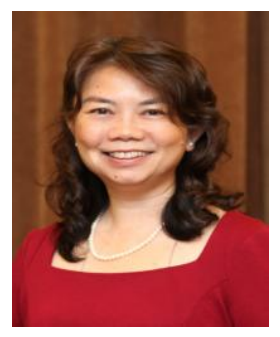

Tam Shu Sim is a senior lecturer and the Faculty of Languages and Linguistics at the University of Malaya. She obtained her $\mathrm{PhD}$ in the area of computer-assisted language learning (CALL) and her other research interest include the various aspects of TESL. She has published 5 ISI papers and some peer-reviewed ones in other journals. 


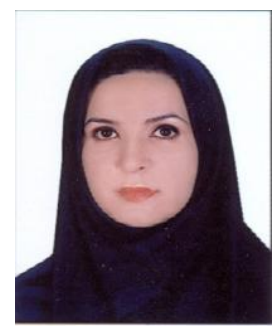

Marziyeh Nekoueizadeh was born in Shiraz, Iran in 1979. She received her M.A. degree in Teaching English as Foreign Language (TEFL) in 2013. She has presented several papers in different national conferences such as International Teacher Education Conference (ITEC 2014). She has also published some papers in peer-reviewed international journals. 